\title{
CHRISTOLOGICAL DISCOURSE IN THE MODERN THEOLOGY OF CATHOLICISM
}

\begin{abstract}
The aim of the article is to explore the Christology models in modern Christianity that demonstrate a reaction to vital sociocultural and spiritual inquiries. This article also aims to realize the importance of Christ for humans to satisfy their needs for addressing some important issues that arise in modern social processes. The theoretical basis of this research is a paper dedicated to a philosophical and religious comprehension of evolutionary processes within the Christological doctrine in the theology of Christian churches. Some of these ideas were put forth by P. Enns, M. Erickson, T. Layne, A. McGrath, Ch. Ryrie, and H. Thyssen. Contributions of other modern scholarly work is from O. Sahan, P. Saukh, L. Fylypovych, and O. Shepetiak. The embodiment of key ideas formulated by the researchers enables us identify some basic aspects of the issue under analysis within a global context. The novelty of this research lies in a complex philosophical and religious analysis of the Christology doctrine content and its influence on modern trends of spiritual development in the context of the general civilization. An important issue lies in the comprehension of models within some Christological doctrines in the Christian thought and their current transformations in the system of methodological items that are interrelated with the personality of Jesus Christ. This understanding comprises a conceptualization of Christ as the world's Savior or historical personality and revelation of boundaries among the nature of Christ and his service. This understand is some kind of literalism in understanding of the Christ incarnation. The article identifies some modern Christological models that aspire to save their innovations within the religious worldview by means of dogmatic ideas (i.e., a constant reference to biblical texts, own theological representatives) together with some cult and institutional aspects (i.e., an intensification of rigor, ritualization, and inner fragmentation). Conclusions. The existence of real Christological views in the Christian thought testifies that theologians of all Christian denominations seek a Christological model construction to satisfy societal spiritual needs and inquiries. In today's changing world, Christian churches have antagonistic positions with respect to globalization and secularization. However, Christian churches demonstrate a modernization of their traditional beliefs and ways of practical activity in view of Christological questions. Nevertheless, the majority of theologians that belong to different Christian faiths improve the existent ideas or develop new conceptions in understanding Christ as the world's Savior or historical personality. Theologians also provide new conceptions in the revelation of boundaries among the nature of Christ and his service. Such
\end{abstract}

\footnotetext{
${ }^{1}$ Oleh Sokolovskyi, DSc PhD, assistant professor in the department of philosophy and political science, Zhytomyr Ivan Franko State University (Zhytomyr, Ukraine); e-mail: osokol_83@ukr.net. ORCID 0000-0003-2228-3040 (corresponding author).

2 Oksana Chaplinska, PhD, assistant professor, head of the department of philosophy and political science, Zhytomyr Ivan Franko State University (Zhytomyr, Ukraine); e-mail: chaplinskay@ ukr.net. ORCID 0000-0002-9702-6906.
} 
an approach encourages a search of Christological doctrine for common tendencies. Through this analysis, we propose a vision for the future and a Christological basis of modern dialogue. However, traditional doctrine discrepancies among Christian confessions prevent a more unified view based on Christological beliefs.

Keywords: Christology, Christianity, religion, social philosophy, Soteriology, theology.

\section{INTRODUCTION}

In the era of globalization a worldview of modern people is getting complicated through the removal of former accepted standards. It is embedded into a religious thought. Under these conditions a problem is brought up to revise the interrelation between an individual and Church that would encourage a spiritual development of humanity. It's absolutely clear the issue can be sorted out on the global level where religious organizations have an important role. The relevance of the research is explained by processes of society secularization that led to the human spiritual crisis as a result of ignoring some traditional Christian values and worldview conceptions. The desacralization of social space became a problem inside the Church. It can be solved only within the implementation of Christian unity. Christology is the most important element since all Christians declare the unity in Christ. Christian churches established different religious traditions and can add spiritual innovations in Eucharist unity of Christ.

Problem statement. The turn from theocentrism to anthropocentrism is deepening in the context of contemporary theology. It was primarily reflected in the existential interpretation of the reality of God; a motivation in peaceful coexistence of people; making close relation between God and human. The modern Catholic theology is represented by a combination of Christian theology beliefs and achievements of modern philosophy. In the $20^{\text {th }}$ century a new comprehension of Christology is one of the main issues of theological reflections. It contradicted to Christian religion in doctrines of some theologians. The Christological problems brought up by modern theologians are establishing a new doctrinal worldview system.

Reasoning of the research novelty. The two basic methods of empirical and theoretical levels of Christology perception are outlined in the modern Catholic theology. They include "ascending Christology" and "descending Christology". The first item presupposes the cognition of Christ via a human existential experience given to some church communities. Such an approach is illustrated in the conceptions of Swiss cardinal Hans von Balthasar, a French theologian and philosopher Teihard de Chardin. Instead, an approach to understanding the Christ identity from the perspective of His historical origin, terrestrial way and service became the basis of Christological doctrines by a German Catholic theologian K. Rahner, a Swiss theologian H. Küng, a German cardinal V. Kasper and Pope emeritus Benedict XVI (Joseph Aloisius Ratzinger).

To discover Christ within Christology is possible under the condition of preserving inseparable unity between Jesus as a man and Christ of faith where the soteriological, anthropological, eschatological and ecclesiological dimensions of Catholicism are exposed in. The Christology doctrine comprehends the meaning of the Jesus resurrection taking into account His death and a sense of death is revealed through His life and acts. That's why the soteriological conception is built on the basis of His life moments, death and Resurrection. 
A Christological synthesis also defines a role of Church in the cognition of Jesus making possible to figure out an initial mission of His nature.

\section{RESEARCH AIM AND TASKS}

The secularization processes needed a certain coordination of scientific and religious worldview. In such conditions the discrepancy is intensifying in Christological views of Christian religious communities. Christology is an integral part for active searches of such a Christian model that would be in harmony with the modern world. The theology renovation took place in the $20^{\text {th }}$ century. It caused an introduction of influential theological fields such as Neo-Thomism, Teyardism, Neoaugustianism, liberation theology in Latin America, "new theology" in France, transcendental and dramatic theology but they didn't formulate a strict position of theological thought.

\section{MAIN MATERIAL STATEMENT}

The modern world globalization processes testified the presence of moral crisis caused by the loss of Christian values. A cultural identity of our epoch must be built on a free human choice that doesn't contradict to freedom of other people's choices. According to some preferences people can choose any religion contrary to the algorithm of traditional religion. It's not the first attack of globalization on traditional cultures and human spiritual life. But the current globalization is much larger-scale than the previous one. It actively interferes in the spiritual life not like in the secondary stuff but like in the self-sufficient spiritual life (Fylypovych, 2010).

This thing encouraged not just priests to rethink boundaries of Christian beliefs interpretation in the information field but also philosophers and religious studies scholars in order to preserve a personal spiritual culture. The Church and society are sure that humanity is able to find ways of most global solutions except a socially worldview algorithm of intercultural interaction where a time bomb is always hidden. Religion grants human communities with a powerful symbolism and also builds up some borders between them turned out to be unassailable for interpenetration. That's why taking globalization as a factor of historical development, it's desirable to aberrate from a popular globalization idea as the process leading to the destruction of traditional cultures. However, there is no denying the fact that the main tendency of modern religious process is its fundamentalism as the reaction on modernism, which brought about a liberalization of doctrinal statements under rethinking with a view of churches adaptation to new social and spiritual conditions (Fylypovych, 2013).

The globalization development always leads to a unification and integration. In the spiritual and religious sense it tends to smoothing of cultural and national religion peculiarities. The consequences of this process aren't dubious. From one perspective, there is a removal of traditional spiritual basics but from another one, it's an unavoidable process to form a particular system of national values. In such a way, the religion evolutionary development of global importance launches not just a loss of national originality but a collecting of general principles being typical of each tradition. That's why globalization needs to be regarded not only as a threat but also an opportunity for various transformations. Only some correctly established priorities will enable us to acquire all preferences from globalization. The long lasting and constant negligence of opportunities will lead to the irretrievable collapsing of interreligious contacts. 
Christian churches in their activity and functionality direct people to their spiritual potential full development. Executing this function they stick to realities of the world. A human inquiry for transcendental beliefs is one of the main features of theology modernization. These claims have grown very rapidly having certain contextual emphases in different social, cultural, political and economic conditions. But in contrast to early Christian movements, neo-orthodox philosophical schools (some views contradict to Christianity and tend to freethinking), modern Christological models aspire to preserve their innovations within a religious worldview. It's achieved due to both dogmatic means (a constant reference to biblical texts, own theologians) and institutional ones (an intensification of rigorism, ritualization and inner fragmentation).

Let us analyze the modern interpretation of Christological doctrine in terms of the most widespread models of Christianity. In this context we pay a special attention to the teaching of the Lord Jesus Christ within the Latin American "liberation theology". Before defining a current direction of the new Christological model development, let us analyze some preconditions of "liberation theology" formation and maturity in the Catholic Church environment. A difficult political, social and economic situation of Latin America in the second half of the $20^{\text {th }}$ century was a source of new theology causing some confrontations among various population segments (Mironov, 2016). A methodological basis of "liberation theology" is "the philosophy of hope" by E. Bloch, "critical theory" by J. Habermas, H. Marcuse and other representatives of Frankfurt school. Catholic church priests became active participants of antagonistic processes. They were leaders of national and revolutionary movements under the pretext of Christian values defense.

A starting point for the formation of liberation theology was the activity of the Second Vatican Council. Its decision defined a direction of problematic matter at the Second Latin American Episcopal Conference (1968 year) in the Colombian city Medellin. During the meeting Catholic bishops tried to implement council regulations under the conditions of Latin America reality. In their rhetoric they used some new notions such as "liberation", "radical changes", "renovations" and "transformations" to convey the urgency of discussed issues. The final documents as a result of conference work illustrated a new church view concerning the solution of difficult political, social and economic situation and were interpreted as "the Big Charter that points out an absolutely new pastoral approach" (Meleshko, 2013). The attitude of clerics to poor and powerless people revitalized a way of social relations on the basis of theological approach focused on Marxism and revolutionary enthusiasm (Mironov, 2016). In such a way the Catholic Church stood up for the protection of suppressed population in Latin America taking the similar further actions.

Pope Paul VI encyclic Populorum Progressio (Development of Nations) became a theoretical basis of liberation theology. He didn't focus on domestic economic issues but international economy (Shepetiak, 2014). On the one hand, the Pope recognized a human right for private ownership in the encyclic. On the other hand, he warned people of monopolism that would restrict their freedom.

The Pope thinks that any progress isn't limited by exclusively economic performance but includes the development of every person: „An individual is capable of self-development according to God's calling" (Benedikt XVI, 2009). In such a way, any social progress starts with a human development on the basis of general support of different communities and institutions. In this respect, the Pope refers to some philosophical fundamentals of human development: „The principles of materialistic and atheistic philosophy are in the heart of any human activity which ignores a religious thought and 
captures human freedom of choice as well as people's dignity" (Benedikt XVI, 2009). Pope Benedict XVI puts emphasis on the prominence of this encyclic paying attention to the importance of social evangelization based on the principles of love, freedom and justice.

The liberation theology appeared as a reaction on church incapability to solve theoretically and practically some social and economic problems of Latin American countries. In this respect, the main emphasis is placed on practice considered to be the most important truth of life by some followers. A search and development of practical recommendations for the implementation of measures to improve the situation are contained in the Holy Scripture texts and Divine Revelation given to people. From the standpoint of hermeneutics, the liberation theology is closer to the protestant exegetics because a return to the Bible authority and a right to interpret it by people correspond to the ideology of the European reformation movement. According to the views of Latin American theologians, the Bible focuses exclusively on the poor in order to activate their struggle for the truth and justice. A saying by F. Herzog sounds good here: "The biblical authority doesn't have any sense if a social issue isn't placed within the central problematics of Eucharist" (Meleshko, 2013).

The embodiment of similar principle from this context explains a denial of church monopoly on a right to interpret the Bible as the truth of last resort. The prerogative is given to all religious people especially those who belong to the poor segments of people. They constitute the main part of Christian community. One of the liberation theology founders Gustavo Gutierrez says: „Reading the Bible is the beginning of dialogue between church members of the past and nowadays: a dialogue taking place in the church community was formed during the entire history" (Meleshko, 2013). The interrelation between the Bible and faith is built exclusively due to practice that revises our faith in God setting up justice and rights for blessing of the poor (Meleshko, 2013).

Despite the actualization of faith issues in the practical field, the liberation theology representatives think that texts of the Holy Scripture are the sacred heritage. A liturgical, spiritual and moral tradition gives answers to inquiries of modern people helping church members to put Christian faith into their personal life. However, the excessive absorption in the tradition and heritage makes possible to identify peculiarities of new text leading to the distortion of the initial Bible meaning: „The tradition delivers experience of previous generations to shape a life according to the God guidance. It establishes a connection between church generations where the word remains a measure of tradition and experience" (Meleshko, 2013).

The liberation theology developed a hermeneutic approach for the text as a model of interaction between an author and reader. The approach appeals to some oppressed segments of population and serves as a way of finding justice to them. Let us mention that a result of such interpretation is the certain ignoring of exegetics since it's necessary to understand a biblical text differently in each specific situation. Most theologians stick to this point of view.

We draw your attention to the mentioned approach that became the basis for the liberation theology of Christological doctrine. A Catholic priest Leonardo Boff tried to systematize the Christological doctrine on the basis of the liberation theology in his book Jesus Christ Liberator. In our opinion it's vital to consider a theologian's methodological approach in the development of his conception about Jesus Christ. From L. Boff perspective, Christology must reveal the most important features of Liberator. It presupposes an advantage of the anthropological element over ecclesiological one, uto- 
pian over evidential, critical over dogmatic, social over personal, "orthopraxy" over "orthodoxy".

The catholic priest within the Christological doctrine emphasized the primacy of people. It enables us to keep own thoughts clear preserving freedom and inner self-sufficiency. Adhering to the unscientific postulate of ideal social system, L. Boff wanted to underscore that the Kingdom of heaven is located on earth and all people are spiritually resurrected in it. A special focus is put on issues of critical attitude towards some ides of the Holy Scripture. It's necessary to separate its liberation content from other information. In L. Boff opinion, a practical integration is also important. It is directed at the implementation of Christian morality ideas and values formulated in the spirit of the Gospel.

Becoming aware of own fragile positions in the developed Christological doctrine that multiplied a low level of trust to the liberation theology, L. Boff tried to bring up his understanding of postulates based on the Christian fundamentals. Defining the main aspects of Church nature, its tasks and a role in the church members life, the theologian stated that despite the supernatural source of its origin, it exists among us expressing itself in the liberation process.

In this statement we see an interrelation of Christology and Soteriology L. Boff combined within two dimensions that is a theological and social dimension. Employing this approach the theologian develops the following relation models such as Chalcedonian, Cultic and Agapian ones (Reati, 2002). In the first model the Chalcedonian formulation of hypostatic connection between the divine and human Christ nature symbolizes the eschatological salvation of Christ being at the same time the Saviour and Liberator. L. Boff considers sacraments as a main element of cult practice. A world reality is directly reflected through them. In this way the historical liberation encompasses salvation on earth. The Catholic priest explains an Agapian model from the position of Christian understanding of love to others and God. Owing to love a person becomes acquainted with the Most High as in the historical liberation a person meets salvation.

The Christology doctrine found its full formulation in the liberation theology model developed by a Salvadorian priest Jean Sobrino. A main work written by the theologian on this issue is considered to be the book Latin American Christology. A story of following historical Jesus. Researching some methodological fundamentals of the modern Christology model represented by the liberation theology, he distinguishes the following three counterparts: ecclesiastical, historic and Trinitarian ones (Reati, 2002).

The church Christology interpreted by J. Sobrino is based on the New Testament adapting the basics of doctrinal and institutional structure of Christian communities to Latin American context with the preservation of theological content. In this Christology model there is a vivid reflection of clerical and social connection grounded on cognition of Christ by the poor. As a result, liberation from oppression is observed. Let us mention that the clerical Christology stands for interests of the poor segments of people interpreting the theology according to changing peculiarities of time. It doesn't fully reveal Christological thoughts in comparison to the official doctrine of Vatican. It includes the hermeneutic approach having a unique and original content.

In the historical model of Christology the New Testament is represented by the story about Jesus who creates a new reality. Owing to this reality any person gets to know the Christ of Faith. The historical Jesus activity according to J. Sobrino is directed at the formation of God's kingdom on earth where people can be called sons of God developing mutual relations on the basis of love, justice and freedom. Such a Christology model is 
compatible with the beliefs of liberal theology seeking for historical Jesus. But in Latin American interpretation it's represented by the reciprocal eschatological and history project for elimination of social injustice. It explains the care of Christ about a destiny of poor, ill and sinful people suffering from wrongdoing of the political system. That's why the historical Jesus activity in the liberation theology is known as an appeal to radical changes in favor of oppressed people (Mironov, 2016). In such a way, the main difference of the liberal and Latin American theology (Christological systems) lies in the absence of opposition between historical Jesus and evangelical Christ within the Latin American theology.

The Christology trinity aspect by J. Sobrino becomes apparent in the creation of God's kingdom by God the Father, its proclamation by God the Son and encouragement of Christ followed by Holy Spirit. The model helps to understand a chain that unites the Holy Trinity that is God the Father, God the Son and Holy Spirit: „The Jesus service on earth is aimed to provide assistance to an oppressed population. Jesus together with God the Father back up freedom and justice in the Latin American continent" (Krylov, 2015). The trinity represents a heaven prototype for terrestrial democracy: "Fundamental democracy tends to equality between people by means of an active cooperation touching the fields of human individual and social existence" (Krylov, 2015).

The trinity Christology and liberty theology in general deal with the important issues related to the distinction of real God and idols, abuse and manipulation with Christian symbols. It's typical of the new millennium. However some aspirations to show Christ as Liberator lead to fixing of Kantian and Marxist postulates inside the liberation theology. They cover a necessity of critical mind and social transformations.

The Christology model of Latin American theology shows Christ as Liberator of people from social and economic oppression making itself politically loaded and focused on a certain group of people (Viter, 2011). At the same time the liberation theology denies a possibility of achievement social equality via radical changes. But under certain circumstances such a course of events is possible. Pope Paul VI says: „Every revolution triggers off new violations of rights and a social balance causing some new destruction processes. That's why it's unacceptable. The exception is a revolution aimed at the overthrow of enduring violent regime that crudely violates basic human rights and undermines welfare of people greatly" (Kokhanovska, 2017).

The Doctrine of Christology gave a way to the existence of ontological, existential and epistemological levels in the Christian thought encouraging a formation of metaphysical, anthropological and soteriological spheres. Deep Christian spirituality norms are developed on the basis of Christology doctrine. Christology enables us to discover a secret of transcendent reality, content of God's revelation and ways of salvation achievement on the theoretical level of religious consciousness. In addition, the confession Christology reflects worldview priorities of certain religious organizations and fills them with some vital life content in the form of regulations. Nowadays Christological models are developing in the scope of Christianity interpreting the personality of Christ according to own beliefs.

A variety of conceptual approaches to understanding of Christ and His service are typical of Christianity what we've already mentioned. In the context of our research we share an opinion of Italian theologian Fiorenzo Reati who interpreted the conceptual approach as a worldview idea within the scope of philosophical categories. The idea determines a research methodology (Reati, 2002). 
A process of Christology doctrine evolution resulted in the creation of conceptual models because there are no instruments to comprehend the personality of Jesus Christ with the help of theological methods of cognition. It enables us to reproduce the originality of initial image even if there is no practical evidence. That's why our cognition is mediated since it's built on the subsidiary structure helping to analyze a prototype when a theoretical pattern is missing. We agree with the French philosopher Alain Badiou point of view. He noted that the formulated model due to certain constructions "doesn't reflect its reality but represents some properties of original stuff through belonging to irreality" (Badiu, 2009). This peculiarity sets up some conditions for a fixation of changes preventing the perception of covert forms considered to be typical of reality. In such a way the methodology of modeling is capable of providing a common range of properties between theories and original forms.

That's why a theological analysis of Jesus Christ teaching is reasonable nowadays. It makes possible to explore a Christology evolution and worldview changes of Christian doctrine bearers. Aspirations to determine the essence of Jesus Christ led to the formation of descending and ascending Christology models functioning as autonomous intellectual constructions in order to cognize the Christ personality. But they aren't full and selfsufficient because they perform a mediatory role among our views about the Christ personality and things we can represent owing to the created models. The doctrines developed by some representatives of ascending and descending Christology are lack of universality. So, they aren't theoretically relevant without a scientifically confirmed hypothesis. The functional content of models appeals to a representation of the Jesus Christ personality as a mediator between theoretical conceptions and His essence. All the aspects can't be limited by this model and other theoretical systems because they tend to be just approaches for understanding of the Christ personality in accordance with a certain methodological angle of view.

The creation of Augustinian model within the Christology is an alternative example of previous variations in aspects of faith and mind correlation. This model underscores the parity between faith and mind. They function independently. And besides, some followers of this approach stick to the idea that faith comes first specifying functioning of mind. It's reasonable to refer to the primary source for understanding the essence of modern approach when solving problems of faith and mind correlation in the scope of the Christological doctrine. In Augustin opinion, a person needs cognition to build a life according to moral principles (Avgustin, 1988). However, a righteous way of life is possible only through following divine instructions that approach a person to God due to faith.

The New Testament liberation messages for conversion and absolution of sins, faith and church preaching must be a basis of Jesus Christ teaching when applying this model to build up Christology. In this context the cerigmatic truth serves as a hypothesis that explains and sums up all evidence. It unites various information about Christ enabling scholars to figure out the truth in the scope of difficult Christological maneuvers. According to some views of modern religion scholars and theologians, the Augustinian model makes possible to interpret historical phenomena credibly and impartially through a life of Christ based on faith of early Christian community. That's why the proposed contemporary Christology model as opposed to the descending and ascending Jesus Christ teaching represents an intellectual structure when discovering some object aspects under analysis. It presupposes an independent nature of scientific cognition models introducing the main features of methodology. 


\section{THE RESEARCH NOVELTY}

Generalizing a great number of Christological conceptions, let us mention, they are close to each other in view of realizing incompleteness of any definition.

An analysis of the Christology doctrine evolution which took place during the whole Christian church history lets us state that understanding of the Second Person of the Holy Trinity was formed on the basis of the New Testament evidence about Jesus. Taking into account different methodological approaches used in Christology, we make a conclusion that a way to cognize Jesus Christ doesn't need to be started with Holy Writ in contrast to previous undertakings. The Gospel gives us initial information about Christ but its further analysis leads us to incapability of understanding His secret. A mental potential is also limited in comprehension.

Accordingly, an analysis of Christology exclusively in the theological context leads to a similar result because a biblical basis is the dogmatic side of the Jesus Christ personality. In our opinion, the Gospel testimony about Jesus Christ explained by the Tradition must be subsidiary one before analyzing personal experience together with the perception of transcendental God in the world. Such an approach turns us to biblical information but an analysis of perception will be practically equal to the New Testament texts. Combining the New Testament testimony, Tradition and personal experience we'll be able to form cognition of Jesus Christ in Christology for the sake of understanding that Christ of faith represented in the Gospel is Jesus of history who lived at the beginning of our era and preached the Kingdom of God, died and resurrected for humanity salvation.

The presence of existent Christological views of Christian thought testifies a situation when theologians of all Christian confessions seek for a development of Christological model that would satisfy spiritual needs of society. In today's rapidly changing world, Christian churches follow antagonistic positions towards globalization and secularization but demonstrate modernization of their traditional beliefs and ways of practical activity in relation to Christological issues.

A great number of theologians who belong to different Christian confessions improve the present conceptions and develop new ones related to the cognition of Christ as the Saviour of the world or historical Personality, revelation of boundaries between the nature of Christ and His service. No wonder it encouraged the formation of Christological models being suitable to vital needs of modern Christian thought development. Such an approach contributes to a search of common Christology beliefs. It tells us about the Christological ground for a modern dialogue opening up some future perspectives. But traditional doctrinal discrepancies between Christian confessions move us away from the unity on the basis of Christological fundamentals.

Nowadays in the context of Christological perspective Christianity demonstrates a reaction to vital social, cultural and spiritual inquiries realizing the importance of Christ for people with their needs of problem solving in modern social processes. The variety of modern world is a reason why Christianity keeps on dividing into numerous movements. Christianity represented by various religious groups can meet spiritual needs of church members.

\section{CONCLUSIONS}

The generalization of basic Christology concepts within the modern Christian thought determines specific Church aspirations to defend biblical statements concerning the Jesus 
Christ personality. It happens due to modernization of religious doctrines on the basis of new terminology. Such an approach brought about the emergence of modern Christology doctrine models that testified the development and need of Christian churches to be close to current political and social processes. The new Christology tendencies have certain peculiarities reflecting age-old historical currents of the Church. The modern Catholic theology is represented by a combination of traditional beliefs of Christian Dogmatics and achievements of modern philosophy. It's reflected in the following aspects such as an anthropological reorientation, testifying the existence of God on the basis of personal and existential experience, reasoning towards ideas of conflict-free society, approaching of transcendental God to the world, removal of gaps between God and any human. In such a way the Christology issues brought up by a range of modern theologians set up a new doctrinal worldview system that needs to be researched carefully.

Christology in Christian thought has always combined some fundamentals of doctrinal statement and philosophical conceptions of Christian thinkers for polemical and apologetic goals. That's why researches of modern Christology doctrine models from the standpoint of philosophy and religion serve as an important factor for comprehension of worldview and cultural processes and their consequences for humanity. The secularization processes of society led to a spiritual crisis of human as a personality as a result of ignoring traditional Christian values and worldview conceptions. A desacralization of social space became the internal Church problem that can be solved only in realization of Christian unity. Its main element is Christology, since all Christians declare a unity in Christ. Christian churches that developed various theological traditions can complement them with spiritual achievements in Eucharistic Unity of Christ. Understanding of Christological discussions with relation to philosophy reflects not only theological traditions of Christian churches but evolution directed at the employment of spiritual potential with a view of harmonizing interreligious relations.

\section{REFERENCES}

Avgustin (1988). O blazhennoj zhizni. Tvoreniya: v 4 t. SPb.: Altejya; K.: UCIMM-Press. Badiu, A. (2009). Kontsept modeli. Vstup do materialistychnoi epistemolohii matematyky. K.: Nika-Tsentr, 232.

Benedikt XVI (2009). Caritas in Veritate: entsiklika o tselostnom chelovecheskom razvitii $v$ lyubvi $i$ istine Verhovnogo Pontifika Benedikta XVI : episkopam, presviteram i diakonam, monashestvuyuschim, vernyim Hristu miryanam i vsem lyudyam dobroy voli. Moskva: Izd-vo Frantsiskantsev, 112.

Fylypovych, L. (2010). Hlobalizatsiia relihiinoho zhyttia ta perspektyvy konfesiinoho rozvytku v Ukraini. "Relihiia ta sotsium" No. 2.

(2013). Fundamentalizatsiia khrystyianstva yak tendentsiia suchasnoho relihiinoho zhyttia. "Relihiia ta sotsium" No. 3-4.

Kokhanovska, M. (2017). Suspilnyi lad u vchenni Katolytskoi tserkvy. "Humanitarnyi korpus: [zbirnyk naukovykh statei z aktualnykh problem filosofii, kulturolohii, psykholohii, pedahohiky ta istorii]” No. 10.

Krylov, P. (2015). Teologiya osvobozhdeniya v Latinskoj Amerike: socialnye idealy i politicheskaya praktika. "Kontury globalnyh transformacij: politika, ekonomika pravo” No. 8 (4). 
Meleshko, A. (2013). Germenevtika bogosloviya osvobozhdeniya: Obschina i svoboda. "Bogoslovskie razmyishleniya: Evro-Aziatskiy zhurnal bogosloviya”. Spetsvyipusk: Bibliya. Bogoslovie. Tserkov.

Mironov, V. (2016). Soyuz kulturyi, nauki, religii (myisli mudretsov). Ch. 3 (gl. 67-97). M.-Berlin: Direkt-Media.

Reati, F. (2002). Bog v XX veke: chelovek - put k ponimaniyu Boga (Zapadnoe bogoslovie XX veka). Sankt-Peterburg: Evropejskij Dom.

Shepetiak, O. (2014). Sotsialne vchennia Tserkvy v entsyklikakh rymskykh pap. "Hileia: naukovyi visnyk” No. 83.

Viter, D. (2011). Neomarksystski idei v suchasnii khrystyianskii teolohii. "Kolehiia. Paradyhmy teolohii, filosofii relihii i relihiieznavstva” No. 7 (20).

DOI: $10.7862 /$ rz.2020.hss.9

The text was submitted to the editorial office: November 2019.

The text was accepted for publication: March 2020. 
